Vol. 4: 407-418.

\title{
Annual variations in the microflora of some varieties of Finnish malting barley
}

Tapani Tuomi and Heikki Rosenqvist

Helsinki University of Technology, Department of Chemical Engineering, Laboratory of Biochemistry and Microbiology, FIN-02150 Espoo, Finland.

\begin{abstract}
Three major Finnish malting barley varieties were studied for annual variations in the incidence of seed-derived fungi, bacteria and actinomycetes. In 1990-1992, 114 characterized fungal, 59 uncharacterized bacterial and 12 uncharacterized actinomycetal isolates were extracted from samples of seed intended for use in malting.

When the yield of the plant hormone, indole-3-acetic acid (IAA), from enriched microbial cultures was weighed against the microbial biomass and the endogenous IAA concentration of the barley harvests, it was concluded that potential exists for bacterial IAA production in biologically significant amounts, given some minor annual variations.

As expected from the average rainfall and temperature during the growing season, microbial counts in all cultivars were highest in 1992. Most of the fungal species found were of saphrophytic character, and field fungi were dominant in the samples. On the whole, microbial counts and spectra in all samples confirmed that each harvest of all cultivars was of good vigour and well suited for malting purposes. Strains of plant pathogenic character included species of Septoria nodorum (Berk) Berk, Drechlera teres (Sacc) Subraim \& Jain, D. sorokiniana (Sacc) Subram \& Jain and D. graminea (Rab.) Shoem.
\end{abstract}

A consistent difference was noted in the microbial infection severities of the cultivars.

Key words: Hordeum vulgare, plant-microbe interactions, indole-3-acetic acid Abbreviations: cfu, colony-forming units; IAA, indole-3-acetic acid

\section{Introduction}

A wide range of bacteria, yeasts and moulds colonize the surface and outer layers of mature barley kernels both in the field and during storage (Briggs 1978, Flannigan 1974). Germination in moist soil exposes the grain to an additional spec- trum of microorganisms under conditions favourable for microbial growth. Penetration of microorganisms is usually arrested by cuticularized layers and highly lignified walls of the surface layers of the grain. Microbial growth appears to extend to the testa-nucellar cuticle, which acts as a barrier to further penetration. However, these mechanical barriers to microbial invasion may 


\section{AGRICULTURAL SCIENCE IN FINLAND}

Tuomi, T. \& Rosenqvist, H.: Fungi and bacteria in malting barley

be weakened when grains crack during drying or harvesting or when the surface layers soften at the high moisture contents required for germination (Briggs 1978). Microflora associated with the grain can cause gushing of undesirable flavours in beer and produce harmful mycotoxins (Amaha and Kitabatake 1981, Chelkowski 1991). These microbes influence the enzymatic activity of wetted grain and alter the quality of malted grain, and on several occasions microbial activity has been noted to interfere with germination (Briggs and McGuinness 1992).

Much remains to be learnt about the mechanisms of microbial action on cereals. In normal circumstances, microbial production of enzymes such as $\beta$-glucan solubilase (Yin et al. 1989) and cellulases (Hoy et al. 1981) is of importance, as are reduced oxygen contents due to microbial activity (Doran and Briggs 1993). One factor that tends to have been overlooked is the microbial production of the plant hormones that influence the germination and growth of the grain. In plants, absolute and relative levels of hormones are instrumental in controlling phenomena such as growth, differentiation, structural organisation and passage from the vegetative to the reproductive phase, as well as other developmental and dynamic events. The effect of endogenous hormone gradients on plants can often be mimicked by applying hormones to plants externally, and thus also by microbes producing and excreting hormones (Davies 1990, Gogola 1991, Haahtela et al. 1990, Loper and Schroth 1986, Rademacher 1992, Rademacher and Graebe 1979, Serrada et al. 1982).

Microbe-derived plant hormones of potential interest for the development, germination and growth of barley kernels include compounds from all main classes of plant hormones, but only bacterial indole-3-acetic acid (IAA) has been estimated to occur in amounts of any significance (Tuomi et al. 1994, 1995). In screening barley grain for microbial IAA production, we previously used three Finnish malting grade barley cultivars of the 1990 harvest. As would be expected, the microbial population of barley varies not only from cultivar to cultivar, but also from year to year. In an effort to see how our results hold up to annual variations in the microbial flora, we in the present study examined variations in the incidence of bacteria, and also of fungi and actinomycetes, in the same three malting barley cultivars in 1990, 1991 and 1992. Our main objective was to evaluate the annual variability in microbial plant hormone production in barley, but in doing so we concurrently acquired additional information on the variations in the microbial spectra and counts of barley.

Previous investigations have given us a good picture of the spectra of epiphytic moulds on the roots, stem bases and leaves of Finnish barley (Mäkelä 1972, 1977 a,b, Mäkelä and Mäki 1980, Mäkelä and Parikka 1980). Less is known, however, about the seed-borne fungi of malting barley, and the few studies that have been published on this subject have used a different methodology and different barley varieties from us (Haikara et al. 1977, Ylimäki 1970, 1981). As a result, several species not heretofore reported in Finnish barley seeds are introduced here, while at the same time many previously encountered species were not found. Since our findings complement the overall picture of the mycoflora of Finnish barley grain, we focus on the general microbiology of the barley samples, which is of interest to all those involved with the processing and cultivation of Finnish barley varieties.

Barley plants grown in temperate, humid regions are parasitized by about ten economically harmful bacterial and fungal foliar pathogens, some of which also attack parts other than foliage. Except for rusts and powdery mildew, most of the foliar-attacking parasites, as well as many of the pathogens causing diseases in roots, are seedborne, and kernel infections frequently discolour kernels and cause loss of quality and crop value (Kiesling 1985, Mathre 1982). All barley foliar pathogens with the exception of rusts have associations with infected crop refuse from previous barley crops. The importance of infected seed in the disease cycle is inversely proportional to the amount of inoculum produced from infected crop refuse. When cultural practices involving little or no tillage and monoculture are 
Vol. 4: 407-418.

combined, the new crop may have extremely high inoculum potential. Under favourable climatic conditions this may cause severe early outbreaks of foliar diseases on plants in the first of the four leaf stages (Kiesling 1985). With this in mind and since the data were at hand - we also look briefly at the pathogenicity of the isolated species, and on the incidence of plant pathogenic species amongst the seeds of different cultivars from harvest to harvest.

\section{Material and methods}

\section{Barley samples}

Dry (moisture content $c a .8$ wt \%), malting-grade grains of the cultivars Kymppi, Kustaa and Hjan Pokko were used. These cultivars are among the four most important barley varieties used by Finnish malt producers (cv. Kilta being the fourth). Kymppi is a two-rowed variety that is also used as fodder (since 1987). Kustaa (marketed in 1980) is reasonably good in yield and has a shorter growing season than other tworowed barley varieties cultivated in Finland. Hjan Pokko (introduced in 1980) is a multirowed variety that gives high yields and is well suited to the production of high-enzyme-content malt (Lampinen 1989).

Fungi and bacteria were isolated from all three cultivars of the 1990, 1991 and 1992 harvests. The samples were taken directly from a malting plant as soon as the new harvests became available. Microbes were isolated within one year of harvesting in 1991-1993. Five parallel plates were prepared at each isolation and enumeration step.

\section{Isolation and enumeration of fungi and bacteria}

Fungi, other than Fusaria, and bacteria were isolated from spread plates prepared from milled
(Frithsch Pulverisette 14, sieve size $0.5 \mathrm{~mm}$ ) grains suspended in physiological salt solution. Potato dextrose agar (PDA, Biokar Diagnostics) containing $0.5 \mathrm{~g} /$ litre ampicillin was used for isolating the fungi, and Plate-count agar (Merck) with $0.01 \mathrm{~g} /$ litre cycloheximide for isolating the bacteria. Fungi were inoculated in both daylight and under near-UV radiation from a black light (Philips, TLD 36W/08) with a 12 h light-dark cycle to induce sporulation. To distinguish isolates, fungi were grown on Malt extract (Merck), Czapek-Dox (Oxoid) and Wort (Difco) agars, as well as on PDA, in both darkness and light. Viable counts of fungi and bacteria in grains were calculated from dilution plates.

Fusarium spp. failed to show up on spread plates and were therefore isolated by direct plating of kernels on Modified Czapek-Dox agar containing iprodione and dichloran (CZID media) according to the method described by Abildgren et al. (1987). Plated kernels were incubated under a daylight lamp (Sylvania, 36W Activa 172). Fungal isolates were identified at the Centraalbureau voor Schimmelcultures in Baarn, The Netherlands. Isolates belonging to the same species were treated separately if they had been isolated from different cultivars. The percentage of kernels contaminated with isolates served as a quantitative measure of Fusarium contamination.

Actinomycetes were isolated and enumerated on spread plates prepared on Starch-casein agar $(10 \mathrm{~g} / \mathrm{l}$ soluble starch; $0.3 \mathrm{~g} / \mathrm{l}$ casein; $2.0 \mathrm{~g} / \mathrm{l}$ $\mathrm{KNO}_{3} ; 2.0 \mathrm{~g} / \mathrm{l} \mathrm{NaCl} ; 2.0 \mathrm{~g} / \mathrm{K} \mathrm{K}_{2} \mathrm{HPO}_{4} ; 0.05 \mathrm{~g} / \mathrm{l}$ $\mathrm{MgSO}_{4} \times 7 \mathrm{H}_{2} \mathrm{O} ; 0.02 \mathrm{~g} / 1 \mathrm{CaCO}_{3} ; 0.01 \mathrm{~g} / \mathrm{l}$ $\mathrm{FeSO}_{4} \times 7 \mathrm{H}_{2} \mathrm{O} ; 15.0 \mathrm{~g} / \mathrm{l}$ Bacto agar, Difco), containing $0,0125 \mathrm{mg} / \mathrm{ml}$ cycloheximide, as described by Rand et al. (1976).

\section{Analysis of IAA}

The IAA content of barley grain was analysed according to the method described by Tuomi and Rosenqvist (1995). The method involves purification by solvent partitioning and thin layer chromatography, preparation of trimethylsilyl deri- 
Tuomi, T. \& Rosenqvist, H.: Fungi and bacteria in malting barley

Table 1. Variations in average rainfall and temperatures (T) in the 1990-1992 growing seasons. Values have been summed over cultivation regions I and II as covered by Mustonen et al. 1994, and summed values divided by the number of observation points to get average values for combined cultivation regions I and II. Data from The Finnish Meteorological Institute.

\begin{tabular}{lcccccc}
\hline Period & \multicolumn{2}{c}{1990} & \multicolumn{2}{c}{1991} & \multicolumn{2}{c}{1992} \\
& $\begin{array}{c}\text { Rainfall } \\
(\mathrm{mm})\end{array}$ & $\begin{array}{c}\mathrm{T} \\
\left(\mathrm{C}^{\circ}\right)\end{array}$ & $\begin{array}{c}\text { Rainfall } \\
(\mathrm{mm})\end{array}$ & $\begin{array}{c}\mathrm{T} \\
\left(\mathrm{C}^{\circ}\right)\end{array}$ & $\begin{array}{c}\text { Rainfall } \\
(\mathrm{mm})\end{array}$ & $\begin{array}{c}\mathrm{T} \\
\left(\mathrm{C}^{\circ}\right)\end{array}$ \\
\hline $01.05-30.05$ & 9 & 9 & 12 & 7 & 4 & 11 \\
$31.05-29.06$ & 5 & 15 & 12 & 12 & 7 & 16 \\
$30.06-29.07$ & 16 & 16 & 17 & 17 & 26 & 16 \\
$30.07-28.08$ & 20 & 16 & 30 & 17 & 31 & 14 \\
$30.07-08.08$ & 13 & 17 & 16 & 20 & 14 & 16 \\
$09.08-18.08$ & 31 & 17 & 58 & 15 & 39 & 15 \\
$19.08-28.08$ & 16 & 13 & 16 & 16 & 39 & 12 \\
$01.05-28.08$ & $218^{\mathrm{a}}$ & $107^{\mathrm{b}}$ & $253^{\mathrm{a}}$ & $99^{\mathrm{b}}$ & $205^{\mathrm{a}}$ & $110^{\mathrm{b}}$ \\
\hline
\end{tabular}

a Total rainfall during period

${ }^{b}$ Deviation of the termic period of growth from reference value $(100 \%)$.

vates with $\mathrm{N}, \mathrm{O}$-bis(trimethyl-silyl)trifluoroacetamide (BSTFA) and analysis by gas chromatography-mass spectrometry (GC-MS), using selected-ion monitoring (SIM).

\section{Results and discussion}

\section{IAA production in bacteria}

Nine out of ten bacteria ( $88 \%$ ) in cultivars Kustaa, Kymppi and Hjan Pokko of the 1990 harvest were previously shown to produce IAA (Tuomi et al. 1994, 1995). To estimate the physiological significance of the presence of IAAproducing bacteria, IAA production per bacterial cell in the liquid growth media of the cultured bacteria was weighed against the bacterial counts and the endogenous IAA concentration of barley grains. On the basis of these calculations, we estimated the bacteria in steeped barley to be capable of IAA production in amounts of biological significance (Tuomi et al. 1994, 1995). Bacterial counts in the 1991 and 1992 harvests further support this assumption, since the counts in all samples were higher than the lowest ones found in the 1990 harvests (Fig. 1). As a conse- quence, bacterial IAA production would fall within the limits estimated for the crop of 1990. To further clarify this point, the endogenous IAA concentration in dry kernels (cv. Kymppi, 1992 harvest) was analysed. The result, $123 \pm 63 \mathrm{~g} / \mathrm{g}$ fresh wt, corresponds well with the IAA concentration on which the 1990 estimates were based (195 $\pm 99 \mathrm{~g} / \mathrm{g}$ fresh wt). Counts of fungi, on the other hand, were too low in both 1991 and 1992 - as they were in 1990 (Tuomi et al. 1994, 1995) - for fungal IAA production to be a factor of significance.

\section{Total counts of fungi and bacteria}

In 1992, August was inclined to be a damp and relatively cold month (Table 1). Just before harvesting then, at a very crucial time in the development of the grain microflora, conditions were wet, and the water taken up by the seeds could not evaporate. As expected, the highest bacterial and fungal counts in all cultivars were therefore found in 1992 (Fig. 1), when the weather favoured the attachment and proliferation of these organisms. In 1990 and 1991 no clear differences were seen in the profiles of the total counts of fungi and bacteria. This, too, was to 
Vol. 4: 407-418.
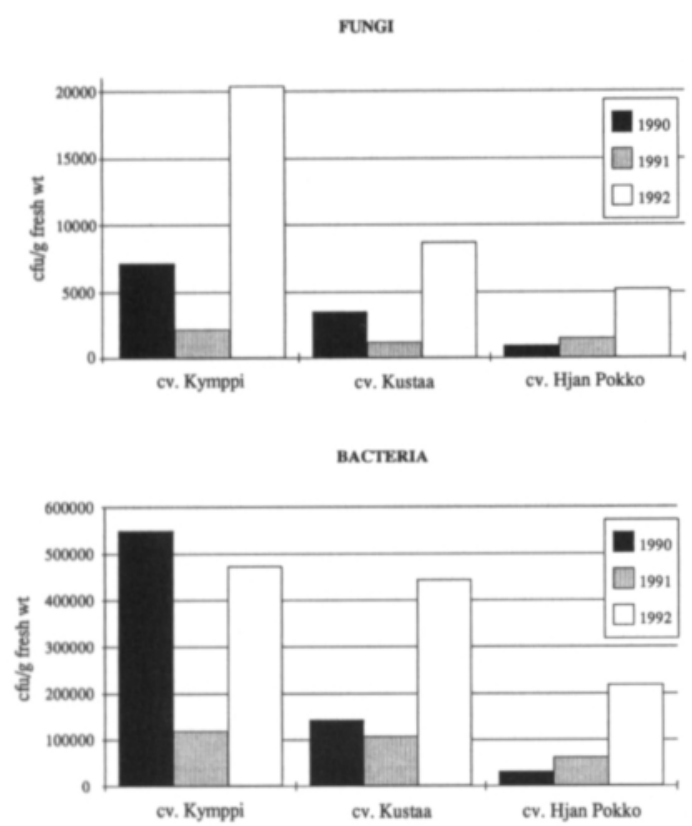

Fig. 1. Total annual viable counts (cfu/g fresh wt of grain) of fungi and bacteria in cvs. Kymppi, Kustaa and Hjan Pokko in 1990-1992.

be expected since there were no marked differences in either average temperatures or rainfall between these years.

In all, 59 uncharacterized bacterial isolates were extracted. Eighteen of these isolates were from the crop of 1990 (6 in cv. Kymppi, 7 in Kustaa and 5 in Hjan Pokko), 24 from that of 1991 ( 8 in cv. Kymppi, 6 in Kustaa and 10 in Hjan Pokko) and 17 from that of 1992 (6 in cvs. Kymppi and Kustaa and 5 in Hjan Pokko). As seen in Figure 1, cv. Kymppi was clearly richest and cv. Hjan Pokko poorest in both bacteria and fungi. The reasons for this are not clear, although one may be that cv. Hjan Pokko has, in terms of surface area, the largest kernels and consequently less surface of attachment per grain than cultivars Kymppi and Kustaa.

Viable counts of actinomycetes in all samples were low in comparison with both bacterial and fungal counts $\left(\leq 10^{2} \mathrm{cfu} / \mathrm{g}\right.$ fresh wt of grain). No attempt was made to characterize these species.

\section{Fungal spectra}

A confusing array of fungi, 114 isolates of yeasts and moulds belonging to 48 different species, were extracted from the three cultivars in 1990 92 (Table 2). The commonest classes are listed in Figure 2, which shows that most of these species were present in all three cultivars and some of them in all three harvests of the cultivars.

Xerophilic storage fungi, namely Aspergillus and Penicillium spp., were in a minority in all samples (Fig. 2) even though the isolation method whould have favoured the appearance of these sporulating species. The levels of both Aspergillus and Penicillium spp. appear to rise, however, when barley is steeped (Douglas and Flannigan 1988, Haikara et al. 1977) and it is therefore important to note that they were present in most of the samples (Fig. 2). As well as harmful mycotoxins, members of both Aspergillus and Penicillium genera are known to produce various plant hormones (Pegg 1984, Tuomi et al. 1994, 1995). Aspergillus spp. and Penicillium spp. also produce many spores that are disseminated by air and can cause respiratory diseases in people and animals (Mathre 1982). Counts of these organisms in the grains would have to be higher than those reported here, however, before they would give any cause for concern. On the contrary, the relatively low counts of these harmful storage fungi indicate that the grains were of good vigour and well suited for malting. One likely reason for the relatively low percentage of storage fungi is that the samples were all taken within a year of harvesting, and the mycoflora would still be dominated by field fungi (Briggs 1978, Burger and LaBerge 1985).

The most conspicuous field fungi were species of Rhodotorula, Cryptococcus and Aureobasidium (A. pullulans), all yeastlike organisms of widespread occurrence (Jay 1986), and species of Drechslera, Cladosporium and Mycelia sterilia (Figs 2-3). Drechslera spp. include species of plant pathogenic interest (see below) and even though not normally cited as occurring in high numbers in barley (Briggs 1978, Douglas and Flannigan 1988, Flannigan 1974, Flannigan 
Tuomi, T. \& Rosenqvist, H.: Fungi and bacteria in malting barley

Table 2. Fungal species isolated from cvs. Kymppi, Kustaa and Hjan Pokko in harvests of 1990, 1991 and 1992.

\begin{tabular}{|c|c|c|c|c|c|c|c|c|c|}
\hline \multirow[t]{3}{*}{ Strain } & \multicolumn{9}{|c|}{ Number of isolates } \\
\hline & \multicolumn{3}{|c|}{ cv. Kymppi } & \multicolumn{3}{|c|}{ cv. Kustaa } & \multicolumn{3}{|c|}{ cv. Hjan Pokko } \\
\hline & '90 & 91 & '92 & ' 90 & '91 & '92 & '90 & '91 & '92 \\
\hline Acrodontium crateriforme (v. Beyma) de Hoog & - & - & - & - & - & - & - & 1 & - \\
\hline Alternaria alternata (Fr.:Fr.) Keissler & 3 & - & 1 & - & - & - & - & - & 2 \\
\hline Alternaria infectoria Simmons & 1 & - & - & - & - & - & 1 & - & 1 \\
\hline Aspergillus flavus Link:Fr. & 1 & 2 & - & - & - & 1 & - & 1 & - \\
\hline Aureobasidium pullulans (de Bary) Arnaud & 1 & 2 & - & - & 2 & 2 & - & 1 & 2 \\
\hline Botrytis cinerea Pers.:Fr. & - & - & - & - & - & 1 & - & - & - \\
\hline Candida spp. & 1 & - & - & - & - & - & - & - & - \\
\hline Chalara austiaca (Faut. \& Lamb.) Nag Raj \& Kendrick & - & 1 & - & - & - & - & - & - & - \\
\hline Cladosporium cladosporioides (Fres.) de Vries & 1 & - & 1 & - & - & 1 & - & 1 & 1 \\
\hline Cladosporium herbarum (Pers.:Fr.) Link & - & - & 1 & - & - & - & - & - & - \\
\hline Cryptococcus albidus (Saito) Skinner var. albidus & - & - & 1 & - & - & 1 & 1 & - & 1 \\
\hline Cryptococcus infirmo-miniatus (okuniki) Phaff \& Fell & - & - & - & - & - & - & - & 1 & - \\
\hline Cryptococcus laurentii (Kufferath) Skinner & - & - & 1 & - & - & 1 & - & - & - \\
\hline Drechslera anam. of Pyrenophora graminea & - & 2 & 1 & - & - & - & - & - & - \\
\hline Drechslera cf. sorokiniana & - & - & - & 1 & - & - & - & - & - \\
\hline Drechslera sorokiniana (Sacc) Subram \& Jain & - & 1 & - & 2 & - & 3 & - & - & 1 \\
\hline Drechslera teres (Sacc.) Shoemaker & - & 1 & - & - & - & - & - & - & - \\
\hline Epicoccum nigrum Link & 1 & - & 1 & - & - & - & - & - & 2 \\
\hline Fusarium spp. & 5 & n.i & n.i & 1 & n.i & n.i & - & n.i & n.i \\
\hline Heterobasidium annosum (Fr.:Fr.) Bref & - & - & - & - & 1 & - & - & - & - \\
\hline Hypocrea pulvinata Fuckel, isol. from Piptoporus betulinus & - & - & - & - & - & - & 1 & - & - \\
\hline Mycelia sterilia & 4 & 2 & - & 2 & 2 & 1 & - & - & 2 \\
\hline Penicillium aurantiogriseum & - & - & - & - & - & - & - & - & 1 \\
\hline Penicillium cf. commune & 1 & 1 & - & - & 1 & - & - & - & - \\
\hline Penicillium corylophilum Dierckx & - & - & - & 1 & 1 & - & - & - & - \\
\hline Penicillium crysogenum Thom & - & - & - & 2 & 1 & - & - & 1 & - \\
\hline Pichia anomala (Hansen) Kurtzman & - & - & - & - & - & - & - & 1 & - \\
\hline Rhodotorula glutinis (Fres) Harrison & 1 & - & - & - & - & 1 & - & 1 & 1 \\
\hline Rhodotorula mucilaginosa (Jörgensen) Harrison & - & - & 1 & - & - & - & - & 1 & - \\
\hline Septoria nodorum (Berk) Berk & - & - & - & 1 & - & 1 & - & - & - \\
\hline Sordaria fimicola (Rob.) Ces. \& De not. & - & - & - & - & - & - & - & 1 & - \\
\hline Sporobolomyces roseus Kluyver \& van Niel. & - & 1 & - & 1 & 1 & - & - & - & - \\
\hline Trichoderma viride Pers:Fr. & 1 & - & - & - & - & - & - & - & - \\
\hline Ucladium botrytis Preuss & - & - & - & - & - & - & - & - & 1 \\
\hline Unidentified spp. & 2 & - & 2 & - & - & 5 & 1 & - & - \\
\hline Williopsis californica (Lodder) Krasil'nikov & - & - & - & 1 & - & - & - & - & - \\
\hline
\end{tabular}

${ }^{n i}$ not isolated

and Healy 1983, Haikara et al. 1977), these fungi appear to be of special importance and spread in Finnish barleys (Mäkelä 1972). The other groups mentioned, A. pullulans and Cladosporium spp. in particular, are more frequent acquaintances among the mycoflora of healthy barley grain (Briggs 1978, Douglas and Flannigan 1988, Flannigan 1974, Flannigan and Healy 1983, Haikara et al. 1977). The Cladosporium spp. found were either isolates of $C$. cladosporioides Fres. de Vries or $C$. herbarum (Pers.:Fr.) Link. C. herbarum (Pers.:Fr.) Link, which was 
Vol. 4: 407-418.
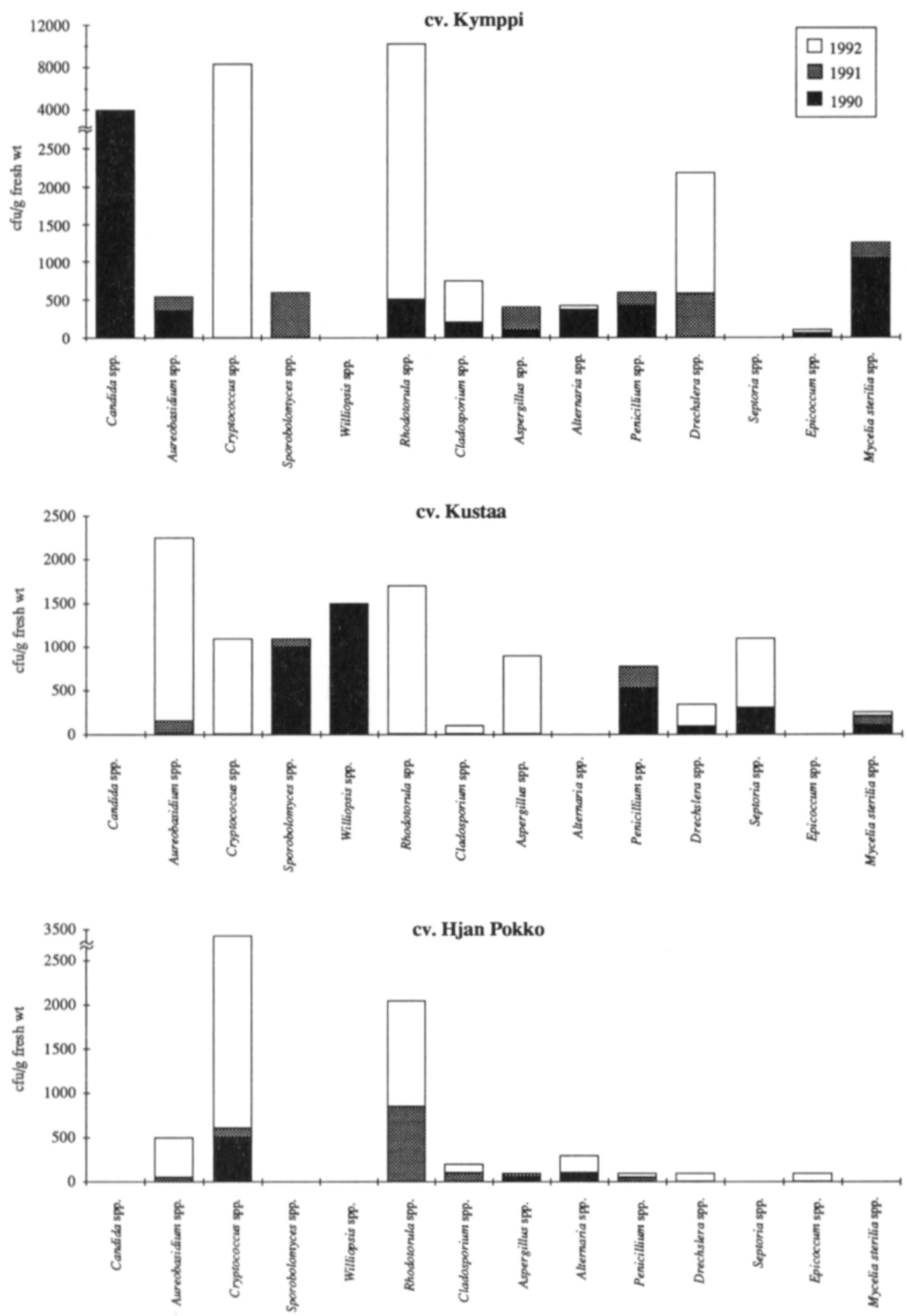

Fig. 2. Viable counts of the fourteen most prominent fungal groups in cvs. Kymppi, Kustaa and Hjan Pokko in 1990-1992. 
Tuomi, T. \& Rosenqvist, H.: Fungi and bacteria in malting barley

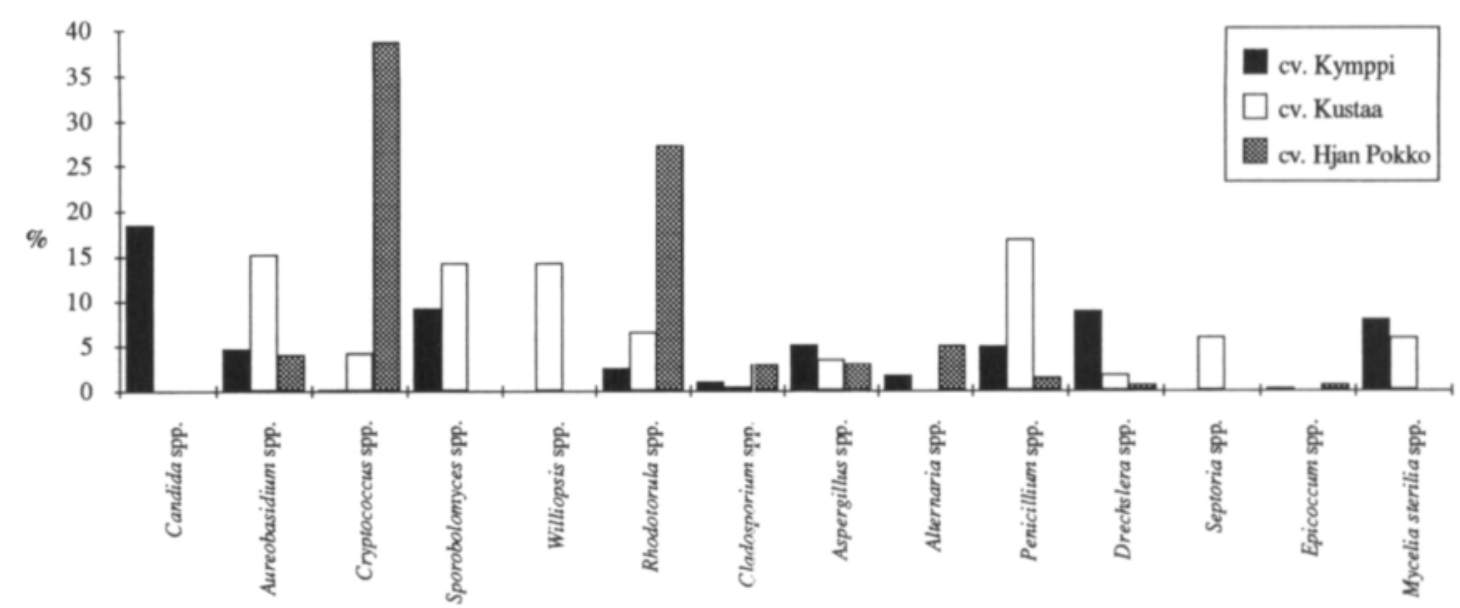

Fig. 3. Mean values of viable counts of the fourteen most prominent fungal groups in cvs. Kymppi, Kustaa and Hjan Pokko in 1990-1992, expressed as percentages of total cfus.

found only in cv. Kymppi of the 1992 harvest, is a saprophyte that frequently parasites weakened or damp grain but, much like C. cladosporioides Fres. de Vries, is relatively unimportant as a seedborne infectant (Flannigan and Healy 1983).

Many of the fungal groups listed in Table 2 have previously been found in barley varieties grown in Finland. Haikara et al. (1977) isolated fungi from four Finnish barley varieties (not cv. Kymppi, Kustaa or Hjan Pokko), and among the seven most common fungal genera listed by them all but Cephalosporium are included in Figures 2 and 3. Clearly, however, most of the fungal groups listed in Figures 2 and 3 are not specific for Finnish barley, most having been cited as common fungi in malting barley by workers using both direct plating and spread plating in different countries the world over (Briggs 1978, Douglas and Flannigan 1988, Flannigan 1974, Flannigan and Healy 1983, Haikara et al. 1977). Ylimäki (1970, 1981) has also investigated the mycoflora of several Finnish barley varieties (not cv. Kymppi, Kustaa or Hjan Pokko), but even though his studies spanned several years and covered grain fresh from harvest as well as samples of stored grain, he does not mention many of the species listed in Table 2. He did, however, list even more species of various genera than are given in Table 2. The reason for this spread in the results is probably that these previous studies utilized direct plating of intact kernels on solid media. Direct plating of fungi on agar or filter paper is an efficient way of isolating filamentous fungi (moulds) from intact seeds but, in our experience, is less suitable for extracting bacteria and yeast-like organisms, which tend to be overgrown and displaced by moulds. Hence, the number of yeasts that showed on our media was higher than would be expected from direct plating. Our results are altogether more compatible with those of, for instance, Flannigan (1974), who used spread plating as well as direct plating to investigate the fungal flora of Bulgarian barley.

In all samples, contamination with Fusarium spp. was too rare for them to appear on dilution plates. Direct plating of corns from the 1990 crops gave a maximum of $10 \%$ of grains contaminated with Fusaria (in cv. Kymppi) and a minimum of $0 \%$ (in cv. Hjan Pokko) (Tuomi et al. 1995). 


\section{AGRICULTURAL SCIENCE IN FINLAND}

Vol. 4: 407-418.

\section{Incidence of plant pathogenic fungi}

All samples contained only smut-free, apparently healthy grain. No reports of outbreaks of major epidemics of economic importance that would concern the harvests of the three cultivars studied here have come to our attention. Nevertheless, some species of plant pathogenic importance were found whose incidence is difficult to link to harvesting yields (Mustonen et al. 1994).

Septoria nodorum (Berk) Berk was present in cv. Kustaa of the 1990 and 1992 harvests. $S$. nodorum, cited as moderately common on tworowed barley in Finland (Mäkelä and Mäki 1980), causes darkening of stems and leaf spots as well as foot and root rot (Mäkelä and Parikka 1980). Seeds are a known source of primary inoculum for this fungus and can harbour $S$. nodorum for up to three years.

Other plant pathogenic species found include species of Drechslera, which occurred in all three cultivars and sometimes in more than one crop (Table 2, Fig. 2); they were, in fact, among the ten most abundant fungi found (Figs 2-3).

The 1991 crop of cv. Kymppi contained Drechslera teres (Sacc) Subraim \& Jain (anamorph of Pyrenophora teres), the causal organism of net blotch (Kiesling 1985). This fungus persists from one growing season to the next as seedborne mycelium or as pseudothecia in infested host residue. Seedborne mycelium probably serves to introduce the pathogen into fields previously free of net blotch (Mathre 1982). In Finland, the fungus has been observed to cause leaf spot on barley, but is probably of minor economic significance (Mäkelä 1972).

Drechslera sorokiniana (Sacc) Subram \& Jain (synonym of Helminthosporium sativum and Bipolaris sorokiniana, anamorph of Cochliobolus sativus) was found in all three cultivars and all three harvests (Table 2, Fig. 2). This fungus is, together with Fusarium culmorum and F. graminearum, cited as a cause of root rot and seedling blight in barley (Mathre 1982). A common fungus in Finnish barley seed, it may have economic significance, as yield losses of up to $11 \%$, with a mean of $6.3 \%$, have been reported in field experiments (Kurppa 1984, 1985b). Seedborne inoculum is the most severe form of primary inoculum and may result in dead or stunted seedlings (Kiesling 1985, Mathre 1982). The infection incidence of Finnish barleys (cvs. Kymppi, Kustaa and Hjan Pokko not considered) and invasion of $D$. sorokiniana to the internal cell layers of kernels is known to vary considerably, and not all varieties are susceptible to pathogenesis (Kurppa 1985a). Since no notable losses have been reported (Mustonen et al. 1994), it is possible that none of these three cultivars is susceptible to $D$. sorokiniana.

The causal organism of barley stripe, Drechslera graminea (Rab.) Shoem. (anamorph of Pyrenophora graminea), was isolated from the 1991 and 1992 crops of cv. Kymppi. This seedborne disease has been common in Finland for a long time and continues to be so (Mäkelä 1972, Mäkelä and Mäki 1980). The primary source of inoculum of this disease, too, is mycelium in infected seed producing systematically infected plants (Teviotdale and Hall 1976). Infected plants produce few seeds, and those that are formed are shrivelled. Losses are therefore directly proportional to the percentage of infected plants in a field. A number of spring barleys have been reported as resistant to the disease, whereas most winter barleys are susceptible (Mathre 1982). Like all malting barleys cultivated in Finland, cv. Kymppi, from which isolates of $P$. graminea were found, is a spring barley.

\section{Conclusion}

In addition to the action of the above plant pathogenic fungi, fungi of the genera Penicillium, Aspergillus, Fusarium, and Alternaria are known to have deleterious effects on the quality of Finnish barleys owing to the production of various toxins. For these species to be of significance, though, higher counts than those reported here (Fig. 2) are required (Hietaniemi and Kumpulainen 1993). In damp years, the infection of Finnish barleys with Fusarium species in particular has caused problems in the processing of 


\section{AGRICULTURAL SCIENCE IN FINLAND}

Tuomi, T. \& Rosenqvist, H.: Fungi and bacteria in malting barley

the grain (Haikara 1983). The small percentage of grains contaminated with Fusaria in our samples does not, however, give cause for concern and, on the whole, all samples seem to have been drawn from barley that - at least in terms of fungal and bacterial counts - were well suited for malting.

Depending on the amounts released, the role of the bacterial IAA reported here might be to inhibit or stimulate germination while also stimulating enzymatic activity (Doran and Briggs 1993, Kieninger 1983, Kieninger and Blohm
1983, Li and Rehmanji 1991, Yamada 1984). In malting trials, similar amounts of added IAA have been noted to enhance the effect of added $\mathrm{GA}_{3}$ (Kieninger 1983, Kieninger and Blohm 1983, Palmer 1971). Whatever its role, bacterial IAA seems to be an intrinsic part of the interaction between germinating barley grain and its hosting bacterial flora.

Acknowledgements. The authors thank MSc. Jouni Ilvesoksa for technical assistance. The work was financially supported by the Foundation for Biotechnical and Industrial Fermentation Research, Finland.

\section{References}

Abildgren, M. P., Lund, F., Thrane, U. \& Elmholt, S. 1987. Czapek-Dox agar containing iprodione and dichloran as a selective medium for the isolation of Fusarium species. Letters in Applied Microbiology 5: 83-86.

Amaha, M. \& Kitabatake, K. 1981. Gushing in beer. In: Pollock, J. R. A. (ed.). Brewing science. Volume 2. Academic Press, London, New York, Toronto, Sydney, San Francisco. p. 457-489.

Briggs, D. E. 1978. Barley. Chapman and Hall, London. $586 \mathrm{p}$.

- \& McGuinness, G. 1992. Microbes on barley grains. Journal of the Institute of Brewing 98: 249-255.

Burger, W. C. \& LaBerge, D. E. 1985. Malting and Brewing quality. In: Rasmusson, D. C. (ed.). Barley. American Society of Agronomy, Crop Science Society of America, Soil Science Society of America, Publishers, Madison, Wisconsin, USA. p. 367-401.

Chelkowski, J. 1991. Fungal pathogens influencing seed quality at harvest. In: Chelkowski, J. (ed.). Cereal grain. Mycotoxins, fungi and quality in drying and storage. Elsevier, London, New York. p. 53-66.

Davies, P. J. 1990. Plant hormones and their role in plant growth and development. Kluwer Academic Publishers, Dordrecht, The Netherlands. $681 \mathrm{p}$.

Doran, P. J. \& Briggs, D. E. 1993. Microbes and grain germination. Journal of the Institute of Brewing 99: 165170.

Douglas, P. E. \& Flannigan, B. 1988. A microbiological evaluation of barley malt production. Journal of the Institute of Brewing 94: 85-88.

Flannigan, B. 1974. Distribution of seed-borne microorganisms in naked barley and wheat before harvest. Transactions of the British Mycological Society 62: 51 58.

- \& Healy, R. E. 1983. The mycoflora of barleys accepted and rejected for malting. Journal of the Institute of Brewing 89: 341-343.

Gogola, N. 1991. Regulation of mycorrhizal infection by hormonal factiors produced by hosts and fungi. Experientia 47: 331-340.
Haahtela, K., Rönkkö, R., Laakso, T., Williams, P. H. \& Korhonen, T. K. 1990. Root-associated enterobacter and Klebsiella in Poa pratensis: characterization of and ironscavenging system and a substance stimulating root hair production. Molecular Plant-Microbe Interactions 3: 35865.

Haikara, A. 1983. Malt and beer from barley artificially contaminated with Fusarium in the field. European Brewery Convention, Proceedings of the 19th Congress, London. p. 401-408.

-, Mäkinen, V. \& Hakulinen, R. 1977. On the microflora of barley after harvesting, during storage and in malting. European Brewery Convention, Proceedings of the 16th Congress, Amsterdam. p. 35-46.

Hietaniemi, V. \& Kumpulainen, J. 1993. Mycotoxins in cereal grains and feeds in Finland. Proceedings from the 25th Nordic Cereal Congress, Helsinki. p. 54-58.

Hoy, J. L., Macauley, B. J. \& Fincher, G. B. 1981. Cellulases of plant and microbial origin in germinating barley. Journal of the Institute of Brewing 87: 77-80.

Jay, J. M. 1986. Modern food microbiology. 3rd ed. Van Nostrand Reinhold, New York. 642 p.

Kieninger, H. 1983. Mãzungsversuche mit 3-indolyl-essigsäure. Brauwissenschaft 9: 352-355.

- \& Blohm, H. 1983. Über die wirkung von 3-indolyl-essigsăure bei der herstellung von malz. European Brewery Convention, Proceedings of the 19th Congress, London. p. 409-416.

Kiesling, R. L. 1985. The diseases of barley. In: Rasmusson, D. C. (ed.). Barley. American Society of Agronomy, Crop Science Society of America, Soil Science Society of America, Publishers, Madison, Wisconsin, USA. p. 269-312.

Kurppa, A. 1984. Bipolaris sorokiniana on barley seed in Finland. Journal of Agricultural Science in Finland 56: 175-182.

- 1985a. The response of some spring barley cultivars grown in Finland to air-borne secondary infection by $\mathrm{Bi}$ polaris sorokiniana. Journal of Agricultural Science in Finland 57: 97-105. 


\section{AGRICULTURAL SCIENCE IN FINLAND}

Vol. 4: 407-418.

- 1985b. The pathogenicity and importance of seed-borne infection by Bipolaris sorokiniana on barley in Finland. Journal of Agricultural Science in Finland 57: 107-115. Lampinen, R. 1989. Peltokasvien viljely, viljakasvit. In: Köppă P. (ed.). Kasvinviljelyoppi 2, Kasvinjalostus, kylvōsiemen, viljelytekniikka, Lănsi Suomi Ltd., Rauma, Finland. p. 78-134.

Li, Y. \& Rehmanji, M. 1991. Effect of abscisic acid analogs on extract yield, $\alpha$-amylase, and diastatic power during malting of barley. Journal of the American Society of Brewing Chemists 49: 135-139.

Loper, J. E. \& Schroth, M. N. 1986. Influence of bacterial sources of indole-3-acetic acid on root elongation of sugar beet. Phytopathology 76: 386-389.

Mathre, D. E. 1982. Compendium of barley diseases. The American Phytopathological Society, Minnesota, USA. $78 \mathrm{p}$.

Mustonen, L., Rantanen, O., Niemeläinen, O., Sankari, H., Kontturi, M. \& Mäkelä, L. 1994. Virallisten lajikekokeiden tuloksia 1986-1993. Maatalouden tutkimuskeskus, Tiedote 2/94. $112 \mathrm{p}$.

Mäkelä, K. 1972. Leaf spot fungi on barley in Finland. Acta Agralia Fennica 124: 2-23.

- 1977a. Hendersonia, Phaeoseptoria and Stagonospora on Gramineae in Finland. Annales Agriculturae Fenniae 16: 238-255.

- 1977b. Septoria and Selenophoma species on Gramineae in Finland. Annales Agriculturae Fenniae 16: 256276.

- \& Mäki, L. 1980. The occurrence of micromycoflora in the stem base and roots of cereals in southern Finland. Annales Agriculturae Fenniae 19: 187-222.

- \& Parikka, P. 1980. Root and foot rot diseases of cereals in southern Finland in 1975-1978. Annales Agriculturae Fenniae 19: 223-253.

Palmer, G. H. 1971. Modes of action of gibberellins during malting. European Brewery Convention, Proceedings of the 13th Congress, Estoril. p. 59-71.

Pegg, G. F. 1984. Pathogenic and non-pathogenic microorganisms and insects. In: Pirson, A. \& Zimmermann, M. H. (eds.). Encyclopedia of plant physiology vol 11. Hormonal regulation of development III, Springer-Verlag, Berlin, Heidelberg, New York, Tokyo. p. 599-624.
Rademacher, W. 1992. Occurrence of gibberellins in different species of the fungal genera Sphaceloma and Elsinoe. Phytochemistry 31: 4155-4157.

- \& Graebe, J. E. 1979. Gibberellin A produced by Sphaceloma manihoticola, the cause of the superelongatiom disease of cassava (Manihot esculenta). Biochemical and Biophysical Research Communications 91: 3540.

Rand, M. C., Greenberg, A. E. \& Taras, M. J. 1976 Standard methods for the examination of water and wastewater. Fourteenth edition. American Public Health Association, American Water Works Association, Water Polution Control Federation. Washington, DC, USA. p. 987-989.

Serrada, J., Sanchez-Serrano, J. J. \& Beltrá, R. 1982. Disease symptoms on plants by non-phytopathogenic bacteria. Phytopathologische Zeitschrift 104: 309-315.

Teviotdale, B. L. \& Hall, D. H. 1976. Factors affecting inoculum development and seed transmission of Helminthosporium gramineum. Phytopathology 66: 295301.

Tuomi, T., Ilvesoksa, J., Laakso, S. \& Rosenqvist, H. 1994. Plant hormone production among fungi and bacteria, inherent to common cultivars of barley. 17th Congress of the Scandinavian Society for Plant Physiology, Elsinore, Denmark, Abstr. No. 3.10. Physiologia Plantarum 91: A8.

-, Laakso, S. \& Rosenqvist, H. 1995. Plant hormones in fungi and bacteria from malting barley. Journal of the Institute of Brewing 101. In press.

- \& Rosenquist, H. 1995. A method for detecting abscisic, gibberellic and indole-3-acetic acid from plants and microbes. Plant Physiology and Biochemistry 33 . In press. Yamada, K. 1984. Changes in the level of endogenous abscisic acid in barley during germination and use of abscisic acid in malting. Journal of the American Society of Brewing Chemists 42: 79-84.

Yin, X. S., MacGregor, A. W. \& Clear, R. M. 1989. Field fungi and $\beta$-glucan solubilase in barley kernels. Journal of the Institute of Brewing 95: 195-198.

Ylimäki, A. 1970. The microflora of cereal seeds in Finland. Annales Agriculturae Fenniae 9: 293-295.

- 1981. The mycoflora of cereal seeds and some feedstuffs. Annales Agriculturae Fenniae 20: 74-88. 
Tuomi, T. \& Rosenqvist, H.: Fungi and bacteria in malting barley

\title{
SELOSTUS
}

\section{Vuosittaisia vaihteluja suomalaisten mallasohrien pieneliöstössä ja niiden vaikutus liotetun ohran indoli-3-etikkahappopitoisuuteen}

\author{
Tapani Tuomi ja Heikki Rosenqvist \\ Teknillinen korkeakoulu
}

Kolmen yleisimmän suomalaisen mallasohralajikkeen jyvien bakteeri-, mikrosieni- (hiiva ja home) ja sädesienipopulaatioiden vuosittaisia vaihteluita tutkittiin vuosina 1990-1992. Työn aikana mallastukseen käytetyistä ohraeristä eristettiin yhteensä 114 karakterisoitua mikrosieni-, 59 tunnistamatonta bakteeri ja 12 tunnistamatonta sädesieni-isolaattia.

Kasvihormonin, indoli-3-etikkahapon, saantoa jyväperäisten mikrobien rikastetuissa puhdasviljelmissä verrattiin mikrobien biomassaan jyvissä ja jyvien indoli-3-etikkahappopitoisuuteen. Todettiin, että ottaen vuosittaiset vaihtelut huomioon, bakteereilla on kyky tuottaa indoli-3-etikkahappoa biologisesti merkittävissä määrin.

Kuten satokausien aikaisten keskilämpötilojen ja sadesummien perusteella saattoi odottaa, bakteeri-, hiiva- ja homemäärät olivat kaikissa lajikkeissa korkeimmillaan vuonna 1992. Suurin osa eristetyistä hiivoista ja homeista lukeutuvat saprofyytteihin. Dominoivia lajeja olivat pellolta peräisin olevat Rhodotorula, Cryptococcus, Aureobasidium, Drechslera, Cladosporium ja Mycelia sterilia. Varastosienet olivat täten vähemmistönä ja kaiken kaikkiaan vaikuttaisi, että kunkin kolmen lajikkeen kaikki kolme vuosikertaa koostuivat mikrobiologisesti hyvälaatuisesta, hyvin mallastukseen soveltuvasta viljasta. Kasvipatogeeneiksi luettavia mikrosienilajeja olivat Septoria nodorum (lehti- ja tähkälaikku) sekä Drechlera teres, D. sorokiniana ja D. graminea (aiheuttavat mm. juurimätää ja taimituhoa).

Mikrobi-invaasioiden määrän havaittiin poikkeavan selvästi ja johdonmukaisesti lajikkeesta toiseen. 